\title{
A tisztességtelen szerződési feltételek vizsgálatának hazai bírói gyakorlata a devizahiteles perekben
}

\section{The Hungarian Judicial Practice of Assessing the Unfairness of Contractual Terms in Foreign Currency Loan Litigations}

Kétség sem férhet ahhoz, hogy a 21. század másodikévtizede a hazai polgári igazságszolgáltatásban a köznyelvben csak „devizahiteles perekként” aposztrofált ügyekröl szól.

Amikor 2008-ban a pénzügyi válság Magyarországot is elérte, a forint jelentősen leértékelödött az euróhoz és a svájci frankhoz képest, ami a devizakölcsönök törlesztörészleteinek jelentös emelkedéséhez vezetett. A devizaalapú kölcsönök tömeges bedôlése a devizahiteles perek lavináját zúdította a bíróságokra. Az adósok által kezdeményezett perek a lakossági fogyasztói szerződések érvénytelenségének megállapítását célozzák, míg a pénzügyi intézmények által indított perek az eladósodott adósokkal szembeni követelés érvényesitésére irányulnak. A peráradat hazai kezelése több csatornán zajlott. Egyrészt intenziv jogalkotás kezdődött, amelynek keretében számos törvényt fogadott el az Országgyúlés. Másrészt beindultak a jogalkalmazásegységesítési mechanizmusok: a Kúria több jogegységi határozatot fogadott el, illetve bírósági határozatot $(\mathrm{BH})$ hozott, továbbá felállította a devizahiteles perek gyakorlatát vizsgáló Konzultációs Testületet, amely az elmúlt évek alatt több - nem kötelezô érvényü, de a bírói gyakorlatot orientáló - véleményt fogalmazott meg.

A devizahiteles perekben különös hangsúlyt kapott a fogyasztók megfelelö tájékoztatása és a szerződési feltételek tisztességtelenségének bírói vizsgálata. Mivel e terület szabályozása jelentős mértékben átitatott az uniós joggal, a bíróságok több esetben is elözetes döntéshozatal iránti kérelemmel fordultak az Európai Unió Bíróságához. Az első ilyen kérelmet egy tucatnyi megkeresés követte.

Simon Károly László a Nemzeti Közszolgálati Egyetem Államtudományi és Nemzetközi Tanulmányok Kar Európai Köz- és Magánjogi Tanszékének egyetemi adjunktusa, a Szekszárdi Járásbíróság bírája. E-mail: Simon.Karoly.Laszlo@uni-nke.hu 
A tanulmány bemutatja a devizahiteles perekben az adósok által leggyakrabban hivatkozott, tisztességtelennek tartott szerződési feltételeket és ezek hazai ítélkezési gyakorlatát.

Kulcsszavak: devizahitel, szerződési feltételek tisztességtelensége, fogyasztói szerződések, devizahiteles perek

There is no doubt that the foreign currency loan litigations have been at the heart of the Hungarian civil justice in the second decade of the $21^{\text {st }}$ century.

When the financial crisis struck Hungary in 2008, the Hungarian Forint continuously depreciated against the EUR and Swiss Francs that resulted a significant increase of the monthly debt payments. The massive collapsing of foreign-currencybased loans and huge losses by citizens have led to numerous litigations before the Hungarian courts. The overwhelming majority of these actions aimed at establishing the invalidity of retail consumer contracts based on the fault of financial institutions and lack of proper information.

On the one hand, intensive legislative work began to balance consumer protection and other interests, and on the other hand, courts adjudicated these cases and the uniform conduct of courts were enhanced through uniformity decisions of the Kúria (Supreme Court of Hungary). In litigation, particular emphasis was placed on providing consumers with adequate information and judicial review of unfair contract terms. Since the regulation of this area has been heavily sourced by the EU law, the courts have in many cases referred questions for a preliminary ruling to the Court of Justice of the European Union. The first such request was the Kásler case (C-26/13) that was followed by a dozen other inquiries.

This paper examines the effects of the decisions made on the basis of the judgements and presents the most frequently invoked unfair contract terms and their Hungarian judicial practice.

Keywords: foreign currency loans, unfairness of contractual terms, consumer contracts, foreign currency loan litigations

\section{Bevezetés}

A 21. század első évtizedében a gazdasági és a lakossági szektor devizaállományának dinamikus növekedését a századelő komplex gazdasági folyamatai idézték elő: a neoliberális gazdaságpolitika, az ebből fakadó deficites állammúködés és államadósság, a tervgazdasági rendszerben frusztrálódott lakosság permanens fogyasztói „paradicsomváró" hangulata, a rendszerváltozás jövedelemfelzárkózást elmulasztó intézkedései, a kamatlábak devizák javára történő elbillenése. A lakosság irányába aktivizálódó kereskedelmi bankrendszer a hiányzó fizetőképes keresletet szolgálta ki a speciális devizahitel-csomagjaival, a fogyasztási hajlandóság kielégítését így nem munkaalapú jövedelmekkel, hanem „olcsó”, de kockázatos devizaalapú fogyasztási kölcsönökkel oldották meg. (Balogh, 2019:13-17; Dancsik et al., 2019:111-129; Lentner, 2015:305-309) 
A hétköznapokban csak „devizahitelnek” nevezett szerződéstípusnak kezdetben a magánjogi megítélése sem volt kristálytiszta sem a jogirodalomban, sem a joggyakorlatban, még a jogszabályok is igen következetlen megnevezéseket használtak a devizahitel-konstrukció megjelölésére. (Fazekas, 2016:80) A bírói gyakorlat számára a Kúria tette egyértelművé a devizahitel fogalmának helyes értelmezését. Eszerint a devizahitelek mögött a hitelintézetekről és pénzügyi vállalkozásokról szóló 1996. évi CXII. törvény (a továbbiakban: rHpt.) által szabályozott pénzügyi szolgáltatások állnak. Az rHpt. 3. § (1) bekezdése a pénzügyi szolgáltatások széles körét nevesíti, a teljesség igénye nélkül ide tartozik: a hitel és pénzkölcsön nyújtása, a pénzügyi lízing, betétgyűjtés, pénzforgalmi szolgáltatások nyújtása, pénzügyi szolgáltatás közvetítése, letéti szolgáltatás, széfszolgáltatás, hitelreferencia-szolgáltatás stb. A „devizahiteles perek” néven elhíresült pertípus kapcsán e pénzügyi szolgáltatások közül a hitel és pénzkölcsön nyújtása, valamint a pénzügyi lízing emelendő ki.

A devizaalapú hitel-, kölcsön- és pénzügyi lízingszerződések devizaszerződések. A devizakölcsön-szerződéseket a forintkölcsön-szerződésektől a kirovó és a lerovó pénznem eltérése különbözteti meg: a felek a hitelezőnek és az adósnak a szerződésből fakadó pénztartozását egyaránt devizában határozták meg (kirovó pénznem), és azt mindkét fél forintban volt köteles teljesíteni (lerovó pénznem). A lakossági hitelezést tekintve jogi értelemben meg kell különböztetni a devizakölcsönt és a devizaalapú kölcsönt. A devizaalapú kölcsönszerződés megkötésekor a kölcsönvevő szándéka arra irányult, hogy forintban jusson a kölcsönhöz, és tartozását is forintban fizesse vissza, kamatfizetési kötelezettsége ugyanakkor a szerződéskötés idején jellemző forintkölcsönre irányadó kamatnál jelentősen alacsonyabb legyen. E szerződéstípusnál az adós az adott időszakban irányadó forintkölcsönnél kedvezőbb kamatmérték mellett devizában adósodott el, a kölcsöntartozást devizában tartották nyilván, ugyanakkor az adós vállalta az árfolyamváltozás kockázatát: a forint gyengülése az adós fizetési terhének (a törlesztőrészleteknek) növekedését, erősödése pedig a csökkenését eredményezte. Devizakölcsönről viszont akkor beszélünk, ha a pénztartozás kirovó és lerovó pénzneme is deviza: ilyenkor a felek úgy állapodnak meg, hogy mindkét fél a kirovó pénznemben (effektivitási kikötés) köteles eleget tenni a szerződésben foglalt kötelezettségének, tehát mind a folyósításra, mind a törlesztésre (azaz a lerovásra) a kirovó pénznemben kerül sor. ${ }^{1} \mathrm{Az}$ árfolyamkockázat ebben az esetben akkor keletkezik, ha az adós a törlesztőrészlet teljesítése előtt a lerováshoz szükséges devizát más devizanem (például forint) átváltásával vásárolja meg. Hazánkban a lakossági hitelek jelentős része svájci frank, kisebb része euró és japán jen alapon keletkezett.

Amikor a 2008-ban kirobbant pénzügyi válság Magyarországot is elérte, a forint jelentősen leértékelődött az euróhoz és a svájci frankhoz képest, ami a devizakölcsönök törlesztőrészleteinek jelentős emelkedéséhez vezetett. A devizaalapú kölcsönök tömeges bedőlése a devizahiteles perek lavináját zúdította a bíróságokra. ${ }^{2} \mathrm{Az}$ adósok által kezdeményezett perek a lakossági fogyasztói szerződések érvénytelenségének megállapítását célozzák, míg a pénzügyi intézmények által indított perek az eladósodottakkal szembeni

A Kúria 6/2013. Polgári jogegységi határozata indokolásának III.1. pontja.

2010 és 2014 között országosan 11860 keresetlevelet nyújtottak be devizaalapú kölcsönszerződések érvénytelenségének megállapítása iránt.

Európai Tükör 2019/3. 
követelés érvényesítésére irányulnak. A peráradat hazai kezelése több csatornán zajlott. Egyrészt intenzív jogalkotás kezdődött, amelynek keretében számos törvényt fogadott el az Országgyúlés. ${ }^{3}$ Másrészt beindultak a jogalkalmazás-egységesítési mechanizmusok: a Kúria több jogegységi határozatot és kollégiumi véleményt fogadott el, ${ }^{4}$ illetve kötelező érvényú bírósági határozatot $(\mathrm{BH})$ hozott, továbbá felállította a devizahiteles perek gyakorlatát vizsgáló Konzultációs Testületet, amely az elmúlt évek alatt több - nem kötelező érvényú, de a bírói gyakorlatot orientáló - véleményt fogalmazott meg. ${ }^{5}$

A devizahiteles perekben az adósi hivatkozások okán különös hangsúlyt kapott a fogyasztók megfelelő tájékoztatása és a szerződési feltételek tisztességtelenségének bírói vizsgálata. Mivel e terület szabályozása jelentős mértékben átitatott az uniós joggal, a bíróságok több esetben is előzetes döntéshozatal iránti kérelemmel fordultak az Európai Unió Bíróságához. Az első ilyen kérelmet a Kásler-ügyben terjesztették elő, amit egy tucatnyi megkeresés követett. Az Európai Unió Bíróságának előzetes döntései szükségszerűen termékenyítőleg hatottak mind a hazai bírói gyakorlatra, mind a jogalkotásra, még akkor is, ha az Európai Unió Bírósága csak néhány ügyben válaszolta meg érdemben a feltett kérdéseket. ${ }^{6}$

\section{A szerződési feltételek tisztességtelensége}

\section{Az rPtk. szabályozása}

A szerződési feltételek tisztességtelenségének mint érvénytelenségi oknak, a devizahiteles perekben irányadó szabályait a 2006. március 1. napjától hatályos Polgári

3 DH1 törvény - a 2014. évi XXXVIII. törvény a Kúriának a pénzügyi intézmények fogyasztói kölcsönszerződéseire vonatkozó jogegységi határozatával kapcsolatos egyes kérdések rendezéséről; DH2 törvény - a 2014. évi XL. törvény a Kúriának a pénzügyi intézmények fogyasztói kölcsönszerződéseire vonatkozó jogegységi határozatával kapcsolatos egyes kérdések rendezéséről szóló 2014. évi XXXVIII. törvényben rögzített elszámolás szabályairól és egyes egyéb rendelkezésekről; DH3 törvény - a 2014. évi LXXVII. törvény az egyes fogyasztói kölcsönszerződések devizanemének módosulásával és a kamatszabályokkal kapcsolatos kérdések rendezéséről (forintosítási törvény). E három törvényt többször is módosították, ezek jórészt technikai jellegú módosítások voltak: DH4 törvény - a 2014. évi LXXVIII. törvény a fogyasztónak nyújtott hitelről szóló 2009. évi CLXII. törvény és egyes kapcsolódó törvények módosításáról (fairbank törvény); DH5 törvény - a 2015. évi II. törvény a pénzügyi intézmények fogyasztói kölcsönszerződéseivel összefüggő, valamint egyéb magánjogi tárgyú törvények módosításáról; DH6 törvény - a 2015. évi LII. törvény a banki elszámolás során tapasztalt visszaélések elleni fellépéshez szükséges törvények módosításáról; DH7 törvény - a 2015. évi CXLV. törvény az egyes fogyasztói kölcsönszerződésekből eredő követelések forintra átváltásával kapcsolatos kérdések rendezéséről.

4 A 2/2012. (XII. 10.) Polgári Kollégiumi (PK) vélemény a fogyasztói kölcsönszerződésben a pénzügyi intézmény által alkalmazott általános szerződései feltételekben szereplő egyoldalú szerződésmódosítási jog tisztességtelenségéről; 6/2013. PJE határozat, 2/2014. PJE határozat, 1/2016. PJE határozat. A Konzultációs Testület emlékeztetői és véleményei elérhetők a https://kuria-birosag.hu/hu/konz-ervenytelensegi (A letöltés dátuma: 2019. 07. 27.) linken.

$6 \quad$ C-26/13. sz. Kásler-ügy [ECLI:EU:C:2014:282]; C-342/13. sz. Sebestyén-ügy [ECLI: EU:C:2014:1857]; C-567/13. sz. Baczó-ügy [ECLI:EU:C:2015:88]; C-32/14. sz. Sugár-ügy [ECLI:EU:C:2015:637]; C-312/14. Banif Plus Bank-ügy [ECLI:EU:C:2015:794]; C-483/16. sz. Sziber-ügy [ECLI:EU:C:2018:367]; C-38/17. sz. GT-ügy [ECLI:EU:C:2019:461]; C-51/17. sz. Ilyés-ügy [ECLI:EU:C:2018:750]; C-118/17. sz. Dunai-ügy [ECLI:EU:C:2019:207]; C-126/17. sz. ERSTE Bank Hungary-ügy [ECLI:EU:C:2018:107]; C-227/18. sz. VE-ügy [ECLI: EU:C:2018:891]. 
Törvénykönyvről szóló 1959. évi IV. törvény (a továbbiakban: rPtk.) 209-209/A. §-ai határozzák meg. A fogyasztóvédelmi szempontú szabályozás a 93/13/EGK irányelv ${ }^{7}$ átültetésén alapul, így alkalmazásuk az uniós rendelkezések értelmezését is igénylik. (Gombos-Lehóczki, 2019)

Az rPtk. 209. § (1) bekezdése szerint tisztességtelen az általános szerződési feltétel, illetve a fogyasztói szerződésben egyedileg meg nem tárgyalt szerződési feltétel, ha a feleknek a szerződésből eredő jogait és kötelezettségeit a jóhiszeműség és tisztesség követelményének megsértésével egyoldalúan és indokolatlanul a szerződési feltétel támasztójával szerződést kötő fél hátrányára állapítja meg. Az rPtk. 209. § (4) bekezdése értelmében az általános szerződési feltétel és a fogyasztói szerződésben egyedileg meg nem tárgyalt feltétel tisztességtelenségét önmagában az is megalapozza, ha a feltétel nem világos vagy nem érthető. ${ }^{8}$

Az rPtk. 209. § (1) bekezdése az általános és az egyedileg meg nem tárgyalt szerződési feltétel vonatkozásában teszi lehetővé a tisztességtelenség megállapítását. (Fazekas, 2016:77-79; Juhász, 2018:44) A devizahitel mint szerződéses konstrukció a szerződési szabadság elvéből fakadóan nem ütközik jogszabályba és önmagában a szerződéstípus tisztességtelenségének megállapítására nincs lehetőség, ez azonban nem zárja ki a devizakölcsön-szerződés egyes rendelkezései tisztességtelenségének megállapítását. (Bodzási, 2018:65; Bodzási, 2019:65)

Az rHpt. 207. §-a előírja, hogy a pénzügyi intézmény köteles az általa rendszeresen végzett, engedélyezett tevékenységre vonatkozó általános szerződési feltételeit üzletszabályzatba foglalni. Az rPtk. 205/A. § (1) bekezdésének megfelelően általános szerződési feltételeket tartalmaz, továbbá - az üzletszabályzat mellett - a pénzügyi intézmény által közzétett hirdetmény, valamint minden olyan szerződésminta (kölcsönszerződés, lízingszerződés, a különböző célú válfajaik, a kapcsolódó biztosítéki szerződések), amelyet a pénzügyi intézmény több személlyel való szerződéskötés érdekében előre elkészít, és amelyet a felek egyedileg nem tárgyaltak meg. Közömbös a rögzítés módja, és az is, hogy a feltételek a szerződésbe szerkesztve vagy külön okiratban jelennek-e meg. A fogyasztóval kötött szerződésben az általános szerződési feltételekhez hasonló megítélés alá esik az olyan kikötés is, amelyet a pénzügyi intézmény ugyan nem több szerződés megkötése céljából alakított ki, de előre egyoldalúan határozott meg, és a kikötést egyedileg a felek nem tárgyalták meg, vagyis a fogyasztónak nem volt módja arra,

A Tanács 93/13/EGK irányelve (1993. április 5.) a fogyasztókkal kötött szerződésekben alkalmazott tisztességtelen feltételekről (HL L 95., 1993.4.21., 29-34.).

A 93/13/EGK irányelv 5. cikk első mondata kimondja, hogy olyan szerződések esetén, amelyekben a fogyasztónak ajánlott valamennyi feltétel vagy a feltételek némelyike írásban szerepel, ezeknek a feltételeknek világosaknak és érthetőeknek kell lenniük. Ezt a rendelkezést a magyar jogalkotó az irányelv átültetése során eredetileg elmulasztotta a magyar jog részévé tenni, ezért a Bizottság felhívta Magyarországot, hogy 2009. január végéig ültesse át a rendelkezést. A jogalkotó a Bizottság felhívásának - némi késedelemmel - a 2009. évi XXXI. törvénnyel tett eleget, amely megállapította az rPtk. 209. § (4) bekezdését. Mivel ez csupán átültetési hiba volt, ezért e rendelkezés a hatálybalépést megelőzően megkötött szerződésekre is irányadónak kell tekinteni. 
hogy a kikötés tartalmát érdemben befolyásolja, alakítsa, választási lehetősége legfeljebb a szerződéskötéstől való elzárkózásra terjedt ki. ${ }^{9}$

Az rPtk. 209. § (1) bekezdéséből fakadóan szerződési feltétel alatt minden szerződéses rendelkezést érteni kell, amely a szerződő felek jogait és kötelezettségeit érinti, és a pénzügyi szolgáltató a szerződés részévé tesz, az adós pedig azt elfogadja. Az általános szerződési feltételek átvételére és megértésére vonatkozó nyilatkozat azonban nem a felek kölcsönös és egybehangzó akaratnyilatkozata, hanem a felperes egyoldalú nyilatkozata, egyszerú tényállítás, tudomáskijelentés; ez a szerződő felek számára nem határoz meg sem jogokat, sem kötelezettségeket, nem minősül szerződéses kikötésnek, általános szerződési feltételnek, így tisztességtelensége nem is vizsgálható. ${ }^{10}$ Részben hasonló indokkal jutott a Kúria egyik eseti döntésében arra következtetésre, hogy a kölcsönszerződés azon rendelkezése, amely szerint a mindenkor hatályos üzletszabályzat rendelkezései az irányadóak, „nem tisztességtelen szerződéses rendelkezés”: önmagában egy ilyen szerződéses kikötés nem állapít meg jogokat és kötelezettségeket, vagyis nem teljesíti az rPtk. 209. § (1) bekezdésében szereplő tényállási elemeket. ${ }^{11}$

Vitatható ugyanakkor a Szegedi Ítélőtábla egyik egyedi ügyben hozott ítéletének hasonló jogi érvelése, amely szerint: „A [régi] Ptk. 209. § (1) bekezdése értelmében - az egyéb feltételek fennállása esetén - a felek szerződésből eredő jogait és kötelezettségeit meghatározó általános szerződési feltételek minősülhetnek tisztességtelennek. Az általános szerződési feltételeket tartalmazó üzletszabályzatban szereplő fogalom-meghatározások a felek jogairól és kötelezettségeiről nem rendelkeznek, következésképpen fogalmilag kizárt, hogy tisztességtelennek minősüljenek."12 A szerződésben szereplő fogalommeghatározás sajátos normatípus, úgynevezett fogalommeghatározó norma, amely a szerződő felek számára kötöttséget eredményez egy-egy szerződéses fogalom értelmezését illetően. Fogalommeghatározással könnyen kijátszhatók a kógens fogyasztóvédelmi szabályok, így például a kamatos kamat, a kamat feltőkésítésének tilalma stb. Ez pedig nyilvánvalóan a fogyasztó jogait és kötelezettségeit hátrányosan érintheti, ez ellen a fogyasztó a szerződésbeli fogalommeghatározás mint szerződési feltétel tisztességtelenség miatti semmisségének megállapítása kérelmezésével védekezhet.

A tisztességtelenség megállapításának az rPtk. két módját ismeri: vagy a bíróság mérlegelésére bízza azt [rPtk. 209. § (1)-(2) és (4) bekezdés], vagy - kizárva a bírói mérlegelést - a törvényi felhatalmazás [rPtk. 209. § (3) bekezdés] alapján elfogadott 18/1999. (II. 5.) Korm. rendelet minősít bizonyos szerződési kikötéseket tisztességtelen szerződési feltételnek. E két út fő szempontjaival foglalkozik a Kúria 2/2011. PK véleménye.

A mérlegeléssel megállapítandó tisztességtelenségi vizsgálat során a bíróságnak figyelemmel kell lennie a szerződésekre vonatkozó diszpozitív szabályokra is, amelyek a szerződő felek egyensúlyára, a szerződési kockázatok, jogok és kötelezettségek kiegyensúlyozott elosztásának elveire épülnek. Tisztességtelenségre utal ezért az rPtk.

\footnotetext{
9 A fogyasztói kölcsönszerződésben pénzügyi intézmény által alkalmazott általános szerződési feltételekben szereplő egyoldalú szerződésmódosítási jog tisztességtelenségéről szóló 2/2012. (XII. 10.) PK vélemény indokolásának 1. pontja.

10 Szegedi Ítélőtábla Pf.III.20.331/2017/5.; Pécsi Ítélőtábla Pf.V.20.169/2017/5.; Pf.V.20.172/2017/7.

11 BH2018. 341.

12 Szegedi Ítélőtábla Pf.II.20.650/2017/5.
} 
lényeges diszpozitív szabályaitól való eltérés, vagy a jogok és kötelezettségek olyan meghatározása, amely a szerződés céljának a megvalósítását veszélyezteti. ${ }^{13}$

A szerződési feltételek tisztességtelensége vizsgálatának másik módja az ilyen feltételek jogszabályi listázása. A listát a 18/1999. (II. 5.) Korm. rendelet tartalmazza, amely a 93/13/EGK irányelv mellékletében szereplő listát emelte át. A 18/1999. (II. 5.) Korm. rendelet 1 . § (1) bekezdése azokat a szerződési feltételeket tartalmazza, amelyek fogyasztói szerződésben feltétlenül tisztességtelenek (úgynevezett feketelista). A 18/1999. (II. 5.) Korm. rendelet 2. §-a az úgynevezett szürke listát tartalmazza, azaz azokat a kikötéseket, amelyek ellenkező bizonyításig tisztességtelennek minősülnek. Ez utóbbi, szürke listás kikötések esetén a jogalkotó vélelmezi a tisztességtelenséget, de elképzelhetőnek tartja, hogy az adott szerződési konstrukcióban a fogyasztóval szerződő fél olyan többletjogot biztosít a fogyasztó számára, vagy olyan többletkötelezettséget vállal, amely mellett az adott szerződéses kikötés már nem minősül tisztességtelennek.

A szerződési kikötés tisztességtelenségének jogkövetkezményét az rPtk. 209/A. §-a határozza meg. Ennek megfelelően a fogyasztói szerződésben alkalmazott ilyen feltétel semmis, a semmisségre csak a fogyasztó érdekében lehet hivatkozni [rPtk. 209/A. § (2) bekezdés]. A nem fogyasztói szerződésben általános szerződési feltételként a szerződés részévé váló tisztességtelen kikötést a sérelmet szenvedett fél megtámadhatja [rPtk. 209/A. § (1) bekezdés].

A szerződési feltétel tisztességtelenségén alapuló érvénytelenség megállapításának határait részben az rPtk. maga jelöli ki, részben a bírói gyakorlat alakította ki. Az alábbiakban részben az rPtk., részben a bírói gyakorlatban megvizsgált szerződési kikötések szemszögéből nézve tárgyalom a tisztességtelenségi vizsgálat alól kivont területeket, illetve a tisztességtelenségi vizsgálat alá vont egyes adósi hivatkozásokat.

\section{Főszolgáltatást megállapító szerződési kikötés}

Az rPtk. 209. § (5) bekezdése kimondja, hogy a tisztességtelen szerződési feltételekre vonatkozó rendelkezések nem alkalmazhatók a főszolgáltatást megállapító szerződési kikötésekre, ha azok egyébként világosak és érthetők. E rendelkezés a 93/13/EGK irányelv 4. cikk (2) bekezdését ülteti át, amely szerint a feltételek tisztességtelen jellegének megítélése nem vonatkozik a szerződés elsődleges tárgyának a meghatározására. Az Európai Unió Bírósága több ízben kimondta, hogy a „szerződés elsődleges tárgyát” vagyis a „főszolgáltatást” megállapító szerződési feltételeknek azok tekintendők, amelyek a szerződést jellemzik, a szerződés alapvető szolgáltatásait határozzák meg. ${ }^{14}$ Rámutatott arra is, hogy azok a feltételek, amelyek magának a szerződéses kapcsolatnak

2/2011. PK vélemény 3. pontja és az ahhoz füzött indokolás.

C-484/08. sz. Caja de Ahorros y Monte de Piedad de Madrid-ügy [ECLI:EU:C:2010:309], az ítélet 34. pontja.; C-26/13. sz. Kásler-ügy [ECLI:EU:C:2014:282], az ítélet 59. pontja; C-143/13. sz. Matei-ügy [ECLIEU:C:2015:127], az ítélet 53. és 54. pontja; C-96/14. sz. van Hove-ügy [ECLI:EU:C:2015:262], az ítélet 33. pontja; C-186/16. sz. Andriciuc-ügy [ECLI:EU:C:2017:703], az ítélet 35. pontja; Guidance on the interpretation and application of of Council Directive 93/13/EEC of 5 April 1993 on unfair contract terms in consumer contracts [C(2019) 5325 final, 2019.7.22].

Európai Tükör 2019/3. 
a lényegét meghatározó feltételekhez képest járulékos jelleggel rendelkeznek, nem tartoznak a „szerződés elsődleges tárgyának” fogalma alá. ${ }^{15}$

A hitelező a hitel-, illetőleg kölcsönszerződéssel arra vállal alapvetően kötelezettséget, hogy bizonyos pénzösszeget bocsát a hitelfelvevő rendelkezésére, míg az utóbbi a maga részéről alapvetően azt a kötelezettséget vállalja, hogy - általában - kamatokkal növelten előre meghatározott időpontokban visszafizeti ezt a pénzösszeget. ${ }^{16}$ Ennek megfelelően hitel- és kölcsönszerződés esetén nyilvánvalóan jellemző szolgáltatásnak minősül a kölcsönösszegnek és az ügyleti kamatnak meghatározása. Ezt a hazai bírói gyakorlat is alátámasztja. ${ }^{17}$

A devizahiteles perekben a legkardinálisabb kérdésként az árfolyamkockázat adósra hárítása, mint az ügylet különös ismertetőjegye merül fel.

\section{Árfolyamkockázat ${ }^{18}$}

Árfolyamkockázat alatt pénzügyi értelemben a különböző devizák átváltási árfolyamának ingadozása miatt keletkezett kockázatot értjük. A devizahitelek magukban rejtik azt a kockázatot, hogy annak a devizának a forintban jegyzett árfolyama, amelyben a kölcsön felvevője eladósodott, a forinthoz képest emelkedik vagy csökken. A forintnak az adott devizához viszonyított gyengülése a devizahitelek törlesztőrészleteinek növekedésével jár, erősödése pedig azok csökkenésével. Ez a kockázat mind a devizakölcsön, mind a devizaalapú kölcsön kapcsán megjelenik.

Az árfolyamkockázat kapcsán az első „húsbavágó” jogkérdés az volt, hogy a devizahitelszerződések árfolyamkockázatát - a havi törlesztőrészletek átváltásából eredő különbözetnek - az adósra telepítő kikötés(e) e szerződések jellemző főszolgáltatásához tartozik-e a 93/13/EGK irányelv 4. cikk (2) bekezdését átültető rPtk. 209. § (5) bekezdése értelmében, igenlő válasz esetén ugyanis e szerződéses kikötés tisztességtelensége főszabály szerint nem vizsgálható. Ennek konkrét esetre vonatkoztatott tényleges eldöntését az Európai Unió Bírósága a Kásler-ügyben a magyar bíróságokra hagyta: „A kérdést előterjesztő bíróságnak kell a kölcsönszerződés természetére, általános rendszerére és kikötéseire, valamint jogi és ténybeli összefüggéseire tekintettel megítélnie, hogy a havi törlesztőrészletek átváltási árfolyamát meghatározó feltétel az adós azon szolgáltatása alapvető elemének minősül-e, amely abból áll, hogy a hitelező által a rendelkezésére bocsátott összeget visszafizesse." ${ }^{19}$ Az árfolyamkockázatnak a devizakölcsönök alapvető szolgáltatáshoz tartozásának kérdését a Kúria 2/2014. PJE határozatának 1. pontja döntötte el, amely szerint: „A deviza alapú fogyasztói kölcsönszerződés azon

15 C-26/13. sz. Kásler-ügy [ECLI:EU:C:2014:282], az ítélet 50. pontja; C-96/14. sz. van Hove-ügy [ECLI:EU: C:2015:262], az ítélet 33. pontja; C-186/16. sz. Andriciuc-ügy [ECLI:EU:C:2017:703], az ítélet 36. pontja; Guidance on the interpretation and application of of Council Directive 93/13/EEC of 5 April 1993 on unfair contract terms in consumer contracts [C(2019) 5325 final, 2019.7.22].

C-186/16. sz. Andriciuc-ügy [ECLI:EU:C:2017:703], az ítélet 38. pontja.

Pfv.I.21.794/2016/4.

A téma részletes kifejtését lásd: (Simon, 2019)

C-26/13. sz. Kásler-ügy [ECLI:EU:C:2014:282], az ítélet 45., 51. és 59. pontja. Az ítélet részletes elemzését lásd: (Gombos-Lehóczki 2019; Fazekas 2017:99-106) 
rendelkezése, amely szerint az árfolyamkockázatot - a kedvezőbb kamatmérték ellenében - korlátozás nélkül a fogyasztó viseli, a főszolgáltatás körébe tartozó szerződéses rendelkezés, amelynek a tisztességtelensége főszabályként nem vizsgálható." A Kúria 2/2014. PJE határozat 1. pontjának indokolása visszautal a 6/2013. PJE határozat 1. pontjára, amely kifejezetten kimondja, hogy a devizaalapú kölcsönszerződések jellegadó sajátossága többek között az, hogy e szerződéstípusnál az adós az adott időszakban irányadó forintalapú kölcsönnél kedvezőbb kamatmérték mellett devizában adósodott el, amiből következően ő viseli az árfolyamváltozás hatásait.

Egy későbbi román ügyben az Európai Unió Bírósága megerősítette a Káslerítéletben lefektetetteket. Az Andriciuc-ügyben a Kásler-ügy tényállásához hasonlítva az volt a különbség, hogy az Andriciuc-ügyben az adósok devizahitelt és nem devizaalapú hitelt vettek fel. ${ }^{20}$

Összegezve: főszabály szerint sem a devizahitel, sem a devizaalapú hitel esetén nem vizsgálható az árfolyamkockázatot adósra telepítő szerződési kikötés tisztességtelensége. Mindez azonban csak akkor igaz, ha az árfolyamkockázat viselésére vonatkozó szerződési kikötés a fogyasztó számára a szerződéskötéskor világos és érthető volt. E körülmény vitatása esetén a bíróságnak vizsgálnia kell, hogy az adott konstrukció egyik lényegi eleme, az árfolyamkockázat fogyasztók általi viselése világos, érthető szerződési feltétel volt-e. ${ }^{21}$

Amennyiben az árfolyamkockázat kikötését általános szerződési feltétel, illetve egyedileg meg nem tárgyalt szerződési feltétel tartalmazta, és e feltétel tartalma egy általánosan tájékozott, észszerűen figyelmes és körültekintő átlagos fogyasztó számára a szerződéskötéskor - figyelemmel a szerződéskötés valamennyi körülményére, így a szerződés szövegére, valamint a pénzügyi intézménytől kapott valamennyi tájékoztatás tartalmára is - nem volt világos és érthető, ez a főszolgáltatást megállapító feltétel is tisztességtelennek minősülhet, amely a fogyasztói kölcsönszerződés érvénytelenségét (semmisségét) eredményezheti a 2/2014. PJE határozat 1. pontjában és annak indokolásában kifejtettek szerint. ${ }^{22}$

\section{Egyedileg megtárgyalt szerződési feltétel}

Az rPtk. 209. § (1) bekezdése értelmében csak az általános szerződési feltétel és a fogyasztói szerződésben egyedileg meg nem tárgyalt feltétel tisztességtelenségét lehet vizsgálni, nem vizsgálható az egyedileg megtárgyalt szerződési feltétel. A devizahiteles perekben ezért - kétség esetén - mindig tisztázni kell az adott szerződési kikötés jellegét.

A Kúria a 2/2011. PK véleményében foglalkozott az általános szerződési feltétel és az egyedileg meg nem tárgyalt szerződési feltétel jelentéstartalmával. A Kúria 2/2011. PK véleménye szerint: „A [régi] Ptk. 205/A. § (1) bekezdése alapján általános szerződési feltétel az a szerződési feltétel, amelyet az egyik fél több szerződés megkötése céljából egyoldalúan, a másik fél közreműködése nélkül előre meghatároz, és amelyet

C-186/16. sz. Andriciuc-ügy [ECLI:EU:C:2017:703], az ítélet 38. pontja.

2/2014. PJE 1. pontja.

2/2014. PJE határozat III/1. pontjához fủzött indokolás.

Európai Tükör 2019/3. 
a felek egyedileg nem tárgyaltak meg. Ettől különböző az a szerződési feltétel, amelyet az egyik fél egyoldalúan, a másik fél közremúködése nélkül előre határoz meg. A lényegi különbség közöttük az, hogy az általános szerződési feltétel esetében az egyik fél a szerződési feltételt több szerződés megkötése céljából határozza meg, míg az egyoldalúan, előre meghatározott szerződési feltétel esetében nincs ilyen cél. Az általános szerződési feltételnek nem fogalmi eleme az, hogy ténylegesen több szerződésben is alkalmazták, hanem elegendő, ha az egyik szerződő fél egyoldalúan azzal a céllal határoz meg egy feltételt, hogy azt több szerződésben kívánja használni. Fogyasztói szerződésnek mindkét típusú szerződési feltétel részét képezheti. Szabályozásukban közös, hogy az ilyen feltételt alkalmazó felet terheli annak bizonyítása, hogy az általános szerződési feltételt, vagy az egyoldalúan, előre meghatározott feltételt a felek egyedileg megtárgyalták-e. Ha tehát a felek között nem vitás, vagy a bíróság a rendelkezésre álló bizonyítékok alapján azt állapította meg, hogy a felek között olyan fogyasztói szerződés jött létre, amely egyoldalúan, a másik fél közremúködése nélkül előre meghatározott szerződési feltételt tartalmaz, vélelem szól amellett, hogy azt egyedileg nem tárgyalták meg. Ezt megdönteni a fogyasztóval szerződő fél csak úgy tudja, ha minden kétséget kizáróan bizonyítja, hogy a vele szerződő fél részére ténylegesen fennállt a szerződési feltétel tartalmi befolyásolásának a lehetősége. Ez akkor valósul meg, ha a fogyasztónak reális lehetôsége nyílt a szerződési feltételek módosítására, azaz a feltételt előre meghatározó fél ténylegesen is lehetővé tette számára, hogy megfontolás tárgyává tegye annak tartalmát, s azzal kapcsolatban akaratát érvényesítse. Ha a fogyasztóval szerződő fél bizonyítja, hogy a fogyasztó e lehetőséggel nem élve fogadta el a feltételt akkor az már egyedileg megtárgyaltnak minősül. Nem elegendő a vélelem megdöntéséhez, ha a rendelkezésre álló bizonyítékok csak azt igazolják, hogy a fogyasztó a szerződést, illetve az annak részét képező feltételeket csupán azok tartalmát megismerve fogadta el." ${ }^{23}$

A devizahiteles perekben vizsgált kölcsönszerződések túlnyomó többsége egyedileg meg nem tárgyalt szerződési kikötésekből, illetőleg általános szerződési feltételekből tevődik össze. Általában a kölcsönfelvevők „szerződési szabadsága” e feltételek elfogadása vagy elutasítása mellett („take it or leave it”) az igényelt kölcsönösszeg, annak devizaneme, a kifizetés határideje, a törlesztés futamideje, a visszafizetési ütemezés, a törlesztőrészletek fizetési határideje és pénzneme meghatározására korlátozódott. Általában ez utóbbiak vonatkozásában mondható, hogy egyedileg megtárgyalt szerződési feltételekről van szó, ezért ezek tisztességtelenségének vizsgálatára általában nem kerülhet sor.

Ezt mondta ki a Debreceni Ítélőtábla az előtte folyamatban volt egyik ügyben: ha a fogyasztó a kockázatok ismeretében maga választja a devizaalapú kölcsönszerződést, e döntése folytán a szerződésnek a pénzneme egyedileg megtárgyaltnak minősül, ezért e szerződéses kikötés tisztességtelensége nem vizsgálható. ${ }^{24}$ 


\section{Árfolyamkülönbözet és árfolyamrés}

A devizaalapú kölcsönszerződéseknél a pénzügyi intézmény a kölcsönt általában az általa, vagy más pénzügyi intézmény által alkalmazott devizavételi árfolyamon folyósította, míg a fogyasztó a törlesztésekkor a pénzügyi intézmény devizaeladási árfolyama figyelembevételével törlesztette (különnemú árfolyam). (Gárdos-Nagy, 2013:378-380) Tekintve, hogy egy adott időpontban a vételi árfolyam mindig alacsonyabb, mint az eladási, így e szerződéses rendelkezés alapján a pénzügyi intézménynek bevétele, míg a fogyasztónak kiadása keletkezett. ${ }^{25}$

Egy adott időpontban az adott deviza vételi és eladási árfolyama közötti különbséget számszerűen (például $8 \mathrm{Ft}$ ) az árfolyamkülönbözet mutatja meg. Az árfolyamrés pedig azt fejezi ki, hogy az adott deviza vételi és eladási árfolyama az adott időpontban hány százalékban tér el az adott deviza középárfolyamától (például +/- 1\%). ${ }^{26}$

A Kúria először az EBH.2013.G.10. számon közzétett elvi bírósági határozatban foglalkozott az árfolyamkülönbözet és az árfolyamrés mint szerződési kikötés minősítésével. A Kúria ebben a határozatában a lakossági, fogyasztási kölcsönszerződésben a kétnemü devizaárfolyam (vételi és eladási árfolyam) alkalmazása során felmerülő árfolyamkülönbözetet az rHpt. szerinti költségnek minősítette, és - az rHpt. 213. § (1) bekezdésére figyelemmel - kimondta, hogy e költség mértéke feltüntetésének hiánya a szerződés semmisségét eredményezi.

A Kúria a 2/2014. PJE határozatában - a Kásler-ügyben hozott előzetes döntést követően - ismét foglalkozott az árfolyamkülönbözettel. E jogegységi határozat a különnemű árfolyamok alkalmazását mint szerződési feltételt tisztességtelennek nyilvánította, mert ezekkel szemben nem áll a fogyasztónak közvetlenül nyújtott szolgáltatás, így az számára indokolatlan költséget jelent. E szerződéses kikötések azért is tisztességtelenek, mert alkalmazásuk gazdasági indoka a fogyasztó számára nem világos, nem érthető, nem átlátható. A Kúria kimondta: a devizaalapú fogyasztói kölcsönszerződésekben szereplő vételi és eladási árfolyamok mint átszámítási árfolyamok helyett az Magyar Nemzeti Bank hivatalos devizaárfolyama válik a szerződés részévé az rPtk. 231. § (2) bekezdésében meghatározott diszpozitív törvényi rendelkezésre tekintettel, mindaddig, amíg kógens törvényi rendelkezés nem lépett azok helyébe. ${ }^{27} \mathrm{~A}$ Kúria egyúttal az EBH.2013.G.10. számon közzétett határozat elvi bírósági határozatként való fenntartását megszüntette, tekintettel arra, hogy a tisztességtelen költség feltüntetésének a hiánya nem minősíthető jogszabályba ütközőnek. A jogegységi határozatot az ilyen jellegű szerződések ez okból való érvénytelenségének helyes jogcíme körüli vita lezárásaként hozták meg. Az érvénytelenség jogcíme az árfolyamrés (árfolyamkülönbözet) alkalmazása kapcsán tehát nem jogszabályba ütközés, hanem tisztességtelenség, az érvénytelenség pedig csak részleges.

A kúriai jogegységi határozatra ezt követően a jogalkotó is reagált, megalkotta a DH1 és DH2 törvényeket. A DH1 és DH2 törvények az árfolyamréssel kapcsolatos szerződéses kikötés alkalmazásából eredő tisztességtelenséget kiküszöbölték. A DH1

2/2014. PJE határozat indokolásának III/3. pontja.

EBH.2013.G.10.

2/ 2014. PJE határozat 3. pontja; EBH.2014.G.2.

Európai Tükör 2019/3. 
törvény 3. §-ának (1) bekezdése az árfolyamrés alkalmazását már kifejezetten részleges érvénytelenséget eredményező semmis kikötésnek minősítette, a (2) bekezdés értelmében pedig a semmis kikötés helyébe - föszabályként - mind a folyósítás, mind pedig a törlesztés tekintetében a Magyar Nemzeti Bank hivatalos devizaárfolyama lépett.

\section{Kamat, költség, díj egyoldalú megváltoztatása}

Az rHpt. lehetővé teszi az egyoldalú szerződésmódosítási jog kikötését. Az rHpt. 210. § (3) bekezdése szerint fogyasztóval kötött kölcsönszerződésben vagy pénzügyi lízingszerződésben az ügyfél számára kedvezőtlenül kizárólag a kamatot, díjat vagy költséget lehet egyoldalúan módosítani. Egyéb feltétel, ideértve az egyoldalú módosításra okot adó körülmények felsorolását is, egyoldalúan nem módosítható az ügyfél számára kedvezőtlenül. Az egyoldalú módosítás jogát a hitelező akkor jogosult gyakorolni, ha a módosításra okot adó objektív körülmények tételes meghatározását a szerződés tartalmazza, valamint a hitelező árazási elveit írásban rögzítette. Az egyoldalú szerződésmódosítás törvényi feltételeit időben eltérő módon és részletességgel rendezte az $\mathrm{rHpt}$., így a fogyasztóra hátrányosan 2009. augusztus 1. napját megelőzően bármely szerződési feltétel, ezt követően csak a kamatra, díjra, költségre vonatkozó rendelkezések voltak módosíthatók egyoldalúan. Az rHpt. a fogyasztói kölcsönszerződések esetén tehát az egyoldalú szerződésmódosítás jogát elismeri, ugyanakkor - a Ptk. 241. §-ához képest a fogyasztók érdekében - korlátozza is, mivel kizárólag a kamat, költség és a díj tekintetében teszi lehetővé fogyasztói kölcsönszerződés esetén az egyoldalú szerződésmódosítást. Miután az egyoldalú szerződésmódosítás jogát (bár korlátokkal) az rHpt. elismeri, önmagában az egyoldalú szerződésmódosítási jogosultság kikötése tisztességtelennek nem minősülhet, ilyen címen sem támadni, sem pedig azt vizsgálni nem lehet, az rPtk. 209. § (6) bekezdése értelmében ugyanis nem minősülhet tisztességtelennek a szerződési feltétel, ha azt jogszabály állapítja meg, vagy jogszabály előírásának megfelelően határozzák meg. ${ }^{28}$

Az egyoldalú szerződésmódosítás jogának kereteit a Kúria a 2/2012. (XII. 10.) PK véleményében foglalta össze. A devizahiteles perek kapcsán a pénzügyi szolgáltatók egyoldalú szerződésmódosítási joga mint tisztességtelen gyakorlat, ismét fellángolt, ezért a 2/2014. PJE határozat megerősítette a 2/2012. (XII. 10.) PK véleményben foglaltakat. A 2/2014. PJE határozat szerint: „Az egyoldalú szerződésmódosításra lehetőséget adó szerződéses rendelkezések akkor tisztességtelenek, ha nem felelnek meg a fogyasztói kölcsönszerződésben pénzügyi intézmény által alkalmazott általános szerződési feltételekben szereplő egyoldalú szerződésmódosítási jog tisztességtelenségéről szóló 2/2012. (XII. 10.) PK vélemény 6. pontjában kifejtett elveknek (egyértelmű és érthető megfogalmazás elve, tételes meghatározás elve, objektivitás elve, ténylegesség és arányosság elve, átláthatóság elve, felmondhatóság elve, szimmetria elve)."

A DH1 törvény 4. §-a vélelmet állított fel amellett, hogy az egyoldalú szerződésmódosítás lehetőségét tartalmazó fogyasztói kölcsönszerződés vonatkozásában vélelmezni kell annak tisztességtelen jellegét, ha az egyoldalú kamatemelést, költségemelést,

2/2012. (XII. 10.) PK vélemény 1. pontja és az ahhoz füzött indokolás.

Európai Tükör 2019/3. 
díjemelést tesz lehetővé. A DH2 törvény a vélelem megdöntésére az ilyen szerződéses kikötéseket alkalmazó pénzintézeteket feljogosította. Ha a pénzügyi intézmény a DH1 törvény 8 . § (1) bekezdése szerinti határidőben nem kezdeményezte a vélelem megdöntésére irányuló speciális polgári peres eljárás lefolytatását, vagy az ez iránti keresetét a bíróság jogerősen elutasította, vagy a pert megszüntette, a tisztességtelenség törvényi vélelme beállt. A tisztességtelen kikötésekhez érvénytelenségük folytán nem füződhet a felek által célzott joghatás, ez következik az érvénytelenség fogalmából és lényegéből. A tisztességtelen egyoldalú kamat-, költség- és díjemelést lehetővé tevő egyedileg meg nem tárgyalt, illetve általános szerződési feltételeket ezért úgy kell tekinteni, mintha azok nem is váltak volna a szerződés részévé, a szerződés ezek nélkül változatlan tartalommal köti a feleket. A tisztességtelen kikötés ellenére a fogyasztó által történt teljesítéseket a javára a DH2 tv. 4. és 6. §-a alapján a pénzügyi intézmény túlfizetésként volt köteles elszámolni. A DH2 tv. 5. § (7) bekezdése értelmében az elszámolás részét képező új törlesztő részletek megállapítása a tisztességtelen egyoldalú kamat-, költség- és díjemelés nélküli szerződési tartalommal történik. ${ }^{29}$

\section{Jogszabály által megállapitott szerződéses kikötés tisztességtelenségének vizsgálata}

Az rPtk. 209. § (6) bekezdése kizárja azoknak a szerződési feltételeknek a tisztességtelenségi vizsgálatát, amelyeket jogszabály állapít meg, vagy amelyeket jogszabály előírásának megfelelően határoztak meg. Ezt a Kúria a 2/2012. (XII. 10.) PK véleményében, de emellett számos eseti döntésében, illetőleg egyedi ügyben hozott határozatában is megerősítette.

A 2/2012. (XII. 10.) PK vélemény 3. pontjában a Kúria akként foglalt állást, hogy olyan feltétel tisztességtelensége, amelynek tartalmát jogszabály kimerítően (taxatíve) határozza meg, bíróság által nem vizsgálható. Ha a kógens keretszabályt a felek rendelkezési joga tölti meg tartalommal, vagy ha a felek a diszpozitív jogszabályi rendelkezésektől eltérnek, az ilyen feltétel tisztességtelensége vizsgálható.

A következetes kúriai gyakorlat szerint nem vizsgálható annak a szerződéses rendelkezésnek a tisztességtelensége, amely a felek szerződésére egyébként irányadó törvényi szabályozással azonos. ${ }^{30}$ Így például nem érvénytelen a kölcsönszerződés azon kikötése, amely a hitelezőt - szerződéses kikötés nélkül is - megillető jogosultságot ismétel meg. E körbe tartozik a kölcsön azonnali hatályú, úgynevezett rendkívüli felmondási joga abban az esetben, ha a kölcsönre nyújtott biztosíték értéke jelentősen csökkent, és azt az adós a hitelező felszólítására nem egészíti ki, hiszen ezt a körülményt az rPtk. maga értékeli az adós által elkövetett súlyos szerződésszegésnek. ${ }^{31}$ Csak annak

1/2016. PJE határozat indokolásának III.1. c) pontja.

BH2018. 284.

Pfv.V.22.531/2017/12.

Európai Tükör 2019/3. 
a szerződési feltételnek a tisztességtelensége vizsgálható, amely a jogszabály rendelkezését tölti ki tartalommal. ${ }^{32}$

\section{Kezelési költséggel kapcsolatos szerződési kikötés tisztességtelensége}

Az adósok számos ügyben kifogásolják a kezelési költség kölcsönszerződésben való szerepeltetését. Gyakori az a hivatkozás, hogy ez a költség ellentételezés nélküli költség, emögött nem áll banki szolgáltatás, a kölcsönszerződésből és az üzletszabályzatból sem derül ki a kezelési költség fejében végzett banki szolgáltatás tartalma. Előfordul olyan érvelés is, hogy a kezelési költség devizában nyilvántartott, noha tartalmilag a kölcsönügylettel kapcsolatban felmerülő, adminisztrációért felszámított díj, márpedig Magyarországon semmi nem indokolja, hogy devizaalapon legyen nyilvántartva, hiszen az árfolyamváltozás következtében a pénzügyi intézmény oldalán felmerülő, a technikai-személyi feltételek biztosítására fordított kiadások nem emelkednek. Ez a feltétel tisztességtelen azért, mert a kezelési költség devizában történő elszámolása a pénzintézet részéről haszonelemeket tartalmaz, burkolt ügyleti kamatként jelenik meg, így a fogyasztó hátrányára a másik félnek teljesen indokolatlanul egyoldalú előnyt biztosít.

Az egységesnek tűnő ítélőtáblai gyakorlat szerint a kezelési költség mint szerződési feltétel tisztességtelensége az rPtk. 209. § (5) bekezdésében foglalt rendelkezésre figyelemmel nem vizsgálható. Az rPtk. 209. § (5) bekezdése értelmében a tisztességtelen szerződési feltételekre vonatkozó rendelkezések nem alkalmazhatók a főszolgáltatást megállapító, illetve a szolgáltatás és az ellenszolgáltatás arányát meghatározó szerződési kikötésekre, ha azok egyébként világosak és érthetők.

A Szegedi Ítélőtábla egyik ítéletében foglalt indokolás szerint: „Az rPtk. 523. § (1) bekezdése a hitelező által nyújtandó főszolgáltatásként meghatározott pénzösszeg adós rendelkezésére bocsátását, azaz a kölcsönösszeg folyósítását jelöli meg. Tekintettel arra, hogy a bankok (pénzügyi intézmények) üzletszerűen foglalkoznak pénzkölcsönzéssel, tömegesen kötnek kölcsönügyleteket - közöttük hosszú távú és a futamidő alatt változó kondíciójú szerződéseket -, szükségszerủ, hogy hitelezési tevékenységüket és az adós teljesítéseit, azok mikénti elszámolását részletesen és pontosan adminisztrálják mind szerződéseik előkészítési, mind azok teljesítési szakaszában. Ezt fejezi ki az rHpt. 2. számú melléklet I.10.3. pontja, amely szerint a hitel és pénzkölcsön nyújtására irányuló pénzügyi szolgáltatási tevékenység a hitelképesség vizsgálatával, a hitel- és kölcsönszerződések előkészítésével, a folyósított kölcsönök nyilvántartásával, figyelemmel kísérésével, ellenőrzésével, a behajtással kapcsolatos intézkedéseket is magában foglalja. Ez a banki adminisztráció nem tekinthető a bank önálló szolgáltatásának, elválaszthatatlanul kapcsolódik a kölcsön folyósításához, a bank egyfajta »segédszolgáltatása" (lásd: Szladits Károly: A magyar magánjog, Grill Kiadó, harmadik kötet, 188-189. oldal), része a főszolgáltatásnak. Ez a banki hitelezési tevékenységhez szükségszerűen kapcsolódó adminisztrációs tevékenység nyilvánvalóan nem elhanyagolható költséggel jár, amely költséget a hitelező vagy az ügyleti kamatba beépítve érvényesíti az adóssal

BH2018. 256.; Pfv.VI.21.573/2017/4., Gfv.VII.30.610/2017/6., Pfv.V.21.628/2017/5.; Pfv.V.22010 /2017/4. 
szemben, vagy külön nevesítve kezelési költség címén tart arra igényt. Mindebből következően a kezelési költség a hitelintézet által nyújtott főszolgáltatás ellenértékének egyik eleme, ennek megfelelően a kezelési költségre vonatkozó általános (vagy egyedileg meg nem tárgyalt) szerződési feltétel a szolgáltatás és az ellenszolgáltatás arányát meghatározó szerződési kikötés, így csak akkor minősülhet tisztességtelennek, ha nem világos, nem érthető.

Az érthetőség és világosság követelményének való megfelelés vizsgálata szempontjából nincs meghatározó jelentősége annak, hogy az adott szerződés tartalmaz-e arra vonatkozó rendelkezést, hogy az abban kikötött kezelési költség konkrétan milyen banki adminisztrációs tevékenység ellentételezésére hivatott. Köztudomású ugyanis, így egy átlagos múveltségű, tájékozottságú fogyasztó előtt is tudottnak kell lennie, hogy a bank a hitelügyletekhez kapcsolódóan széleskörú adminisztrációt végez, a szerződéskötés előtt vizsgálja a potenciális adós hitelképességét, a kölcsön folyósítását követően nyilvántartja és elszámolja az adós törlesztéseit, a fennálló tartozás összegéről évente, illetve az adós kérésére ezen kívül is tájékoztatást ad. [...] Mindez egyben azt is jelenti, a kezelési költség fizetését előíró általános, illetve egyedileg meg nem tárgyalt szerződési feltételek érthetőségének, világosságának vizsgálata lényegében arra terjed ki, a fogyasztó számára felismerhető volt-e az érintett szerződési feltételek alapján, hogy milyen mértékủ kezelési költséget kell fizetnie, illetve hogy az minek alapján, hogyan kerül kiszámításra." ${ }^{3}$

Egy másik ügyben az alábbi indokolás olvasható: „Helytállóan utalt ugyanakkor az alperes fellebbezésében arra, hogy a Ptk. 209. § (5) bekezdése szerint a tisztességtelen szerződési feltételekre vonatkozó rendelkezések nem alkalmazhatók a főszolgáltatást megállapító, illetve a szolgáltatás és az ellenszolgáltatás arányát meghatározó szerződési kikötésekre, ha azok egyébként világosak és érthetőek. A kezelési költség valóban a szolgáltatás-ellenszolgáltatás meghatározásának körébe tartozik, a hitelintézet által nyújtott szolgáltatás (kölcsönnyújtás) ellenértéke, illetve annak egyik eleme. Az ügyletkötéskor hatályos 41/1997. (III. 5.) Korm. rendelet előírásainak megfelelően meghatározott teljes hiteldíjmutató (THM) tartalmazza a kölcsönszerződés alapján fizetendő összes díjat, ennek egyik elemeként értékelték a felek szerződésükben a százalékos mértékben meghatározott, ennélfogva kamat jellegű kezelési költséget is. Mivel a kezelési költség számítása a szolgáltatás és ellenszolgáltatás arányát meghatározó kikötésnek minősül [Ptk. 201. § (3) bek.], ezért az a Ptk. 209. § (5) bekezdés korlátozó szabálya folytán a bíróság által érdemben - a kikötés tisztességtelen megítélése szempontjából - nem volt vizsgálható." 34

A kezelési költségre vonatkozó szerződési feltételeket a Kúria megkeresésére az Európai Unió Bírósága is vizsgálta a Kiss-ügyben. Az ítélet rímel a Szegedi Ítélőtábla fentebb idézett határozatára: a világos és érthető megfogalmazás követelménye nem kívánja meg, hogy a fogyasztói kölcsönszerződésben foglalt, olyan szerződési feltételekben, amelyek a fogyasztót terhelő kezelési költség és folyósítási jutalék összegét, azok

Szegedi Ítélőtábla Pf.II.20.678/2017/13.

BDT2012.2739.; lásd még: Debreceni Ítélőtábla Pf.II.20.356/2016/4.; Szegedi Ítélőtábla Pf.II.20.116/ 2016/4.; Győri Ítélőtábla Pf.I.20.065/2016/5.; Fővárosi Ítélőtábla 10.Gf.40.198/2016/3.; 16.Gf.40. 400/2016/6.; Debreceni Ítélőtábla Pf.I.20.495/2018/8. 
kiszámításának módját és teljesítésének idejét pontosan meghatározzák, az érintett összegek ellenében nyújtott valamennyi szolgáltatást is részletezzék. ${ }^{35}$

\section{A hitelképesség hanyag vizsgálata}

Többször előforduló adósi hivatkozás, hogy a kölcsönvevő eladósodásához a pénzintézet hanyag hitelképességi vizsgálata vezetett. Az érvelés lényege szerint a pénzügyi szolgáltató kötelezettsége lett volna az adós hitelképességének vizsgálata, észlelnie kellett volna, hogy az adós nem lesz képes magasabb törlesztőrészlet megfizetésére. Az alperes ezzel megsértette az rHpt. 77. § (1) bekezdésében, 78. § (1) bekezdésében írt elveket, nem kellő gondossággal végezte el a hitelbírálatot. A szerződésből eredő kockázat egyik félre hárítása így a szimmetria elvével ellentétes.

Az rHpt. 77-78. §-ai többek között azt írják elő, hogy a pénzügyi intézmény köteles a kihelyezések és kötelezettségvállalások megalapozottságát, áttekinthetőségét a kockázatok felmérését, ellenőrzését és csökkentését lehetővé tevő belső szabályzattal rendelkezni. Előírja továbbá, hogy a pénzügyi intézménynek meg kell győződnie a szükséges fedezetek meglétéről, valós értékéről és érvényesíthetőségéről, illetve arról, hogy mi nem fogadható el fedezetként.

A Kúria egyik egyedi ügyben hozott határozatában rámutatott: a hitelképesség bank általi, gondatlan vagy helytelen felmérésének esetleges megállapítása sem vezetne a szerződés érvénytelenségének megállapítására, ezért ennek vizsgálata szükségtelen, e tény a szerződés érvényessége szempontjából közömbös. ${ }^{36} \mathrm{~A}$ Kúria itt visszautal a 2/2016. számú elvi bírósági döntésben foglaltakra. Az EBD2016. P.2. számú döntés ennek kapcsán kifejti: „Az rPtk. 200. § (2) bekezdése szerint az a szerződés semmis, amely jogszabályba ütközik, kivéve, ha ahhoz a jogszabály más jogkövetkezményt fúz. A következetes bírói gyakorlat szerint a más jogági szabályokat sértő szerződés a polgári jog szempontjából akkor érvénytelen, ha a más jogági törvény kifejezetten rögzíti, hogy az adott jogi norma megsértése egyúttal a szerződés érvénytelenségét is okozza, vagy ha ez a törvény értelmezéséből, az összes körülményből nyilvánvaló módon megállapítható (BDT2006. 1450., BDT2000. 97.). A hatósági engedélyhez kötött tevékenység esetén az engedély hiánya önmagában nem érinti az ügylet polgári jogi érvényességét, az csak akkor állapítható meg, ha a jogalkotó felismerhetően a szerződés érvényességét sem kívánta megengedni (BDT2000. 97., EBH2002. 646.). ${ }^{37}$ Mivel sem az rHpt., sem az rPtk. nem fúzi a hanyag hitelképesség-vizsgálathoz a szerződés érvénytelenségének jogkövetkezményét, így annak megállapítására jogszabályi lehetőség nincs.”

C-621/17. sz. Kiss-ügy [ECLI:EU:C:2019:820], az ítélet 45. pontja

Gfv.VII.30.494/2018/3.

EBD2016. P.2.

Európai Tükör 2019/3. 


\section{Értékbecsló kizárólag pénzintézet általi kiválasztása}

A gépjármű- és ingatlanvásárlás céljából felvett kölcsönszerződések gyakori szerződéses feltételeként szerepel, hogy a szerződés felmondása és ennek következményeként a finanszírozott gépjármű vagy ingatlan bírósági végrehajtás mellőzésével történő értékesítése esetén az értékesítésre azon a legalacsonyabb eladási áron kerülhet sor, amelyet a bankkal szerződéses kapcsolatban álló, a tevékenység végzésére megfelelő jogosítványnyal rendelkező, értékbecsléssel foglalkozó cégek vagy egyéni vállalkozók valamelyike meghatározott.

Többször előfordul az ehhez hasonló szerződéses rendelkezés tisztességtelenségének megállapítására irányuló kérelem.

A Kúria ezzel kapcsolatban rámutatott: „A rPtk. 257. § (1)-(2) bekezdései nem minősülnek olyan törvényi rendelkezésnek, amelyek kimerítően, eltérést meg nem engedően szabályozzák a zálogtárgy végrehajtáson kívüli értékesítésére vonatkozó szabályokat, a jogszabályban foglaltakat a szerződésben kell kitölteni tartalommal. Így a per tárgyát képező szerződéses rendelkezések tisztességtelensége vizsgálható. [...] Az olyan szerződéses rendelkezés, amely kizárólagosan a bankot jogosítja fel az értékbecslő kiválasztására, kizárólag a bankkal szerződéses kapcsolatban álló értékbecslők közül biztosítva a kiválasztás lehetőségét oly módon, hogy az értékbecsléssel szemben hatékony jogorvoslatot sem jogszabály, sem a szerződéses rendelkezés nem biztosít, tisztességtelen."38

\section{Azonnali hatályú felmondás a bank részérōl}

Az egyik bank általános szerződési feltételei tartalmazták azt a kitételt, hogy „a bank jogosult a szerződést azonnali hatállyal felmondani, ha szerződésszegési esemény következik be, és szerződésszegési eseménynek minősül, ha az Általános Szerződési Feltételekben, szerződésben, illetve a biztosítéki szerződésben az Üzletfél/Adóstárs/ Kezes/Biztosítékot nyújtó személy az őt terhelő bármely kötelezettséget nem teljesíti”.

A Kúria ezt a szerződési feltételt tisztességtelennek találta, érvelésének lényege a következő volt: „A 'bármely kötelezettség nem teljesítése', amely adott esetben semmiféle összefüggésben nem áll az Üzletfél/Adóstárs/Kezes/Biztosítékot nyújtó személynek a III. rendű alperes irányában fennálló főkötelezettsége teljesítésével, nem lehet egyenértékű azzal, hogy a kölcsönre nyújtott biztosíték értéke jelentősen csökkent, és azt az adós a hitelező felszólítására nem egészíti ki; az adós vagyoni helyzetének romlása vagy a fedezet elvonására irányuló magatartása veszélyezteti a kölcsön visszafizetésének lehetőségét; az adós más súlyos szerződésszegést követett el [rPtk. 525. § (1) bekezdés c), d) és e) pont]. Az a megfogalmazás, hogy 'bármely kötelezettség' megszegése, olyan tág teret nyit a banknak az azonnali hatályú felmondás gyakorlására, amiről helyesen állapította meg a jogerős ítélet a tisztességtelenséget. És mert az adott megfogalmazásban megszabott feltétel nem tesz eleget annak a követelménynek, hogy azt

BH2018. 256.; BDT2017. 3717.; Pfv.V.22.535/2017/7.; Gfv.VII.30.067/2018/7.

Európai Tükör 2019/3. 
ilyen tartalommal jogszabály állapította volna meg, vagy jogszabály előírásának megfelelően határozták meg, nem sérült az rPtk. 209. § (6) bekezdése sem."39

\section{Ténytanúsítvány}

Számos pénzügyi szolgáltató általános szerződési feltételként határozza meg a fogyasztási kölcsönszerződés, illetőleg lízingszerződés részét képező üzletszabályzatban, hogy a pénzintézet a szerződésben foglaltak szerint neki járó összegeket, az ügyfél tartozását könyveiben nyilvántartja. A felek a tartozás összege, illetve a finanszírozási dokumentumok alapján a pénzintézet üzleti könyveit és nyilvántartásait tekintik irányadónak, végrehajtási eljárás kezdeményezése esetén pedig a pénzintézet könyvei, nyilvántartásai alapján készült, közokiratba foglalt ténytanúsítványt fogadják el. Ennek megfelelően a követelés fennállása és végrehajtási eljárás kezdeményezése esetén, a végrehajtás alapjául szolgáló, mindenkor fennálló követelést e ténytanúsítvány tanúsítja, amely elfogadására az ügyfelek a lízingszerződés aláírásával kötelezik magukat. Az ügyfelek a közjegyzői okiratba foglalás során az egyoldalú kötelezettségvállalás részeként rendszerint kifejezetten elfogadták, hogy a pénzintézet felkérésére közjegyző vagy közjegyzőhelyettes a pénzintézet velük szembeni követelése mértékét a pénzintézet könyveibe, nyilvántartásába történő betekintéssel közjegyzői tanúsítványba foglaltan tanúsítsa.

A közjegyzőkről szóló 1991. évi XLI. törvény 111. § (1) bekezdése szerint a ténytanúsító okiratban a közjegyző a jogi jelentőségú tényeket közhitelesen tanúsítja jegyzőkönyvi vagy záradéki formában. A hitel-, kölcsön- vagy lízingszerződés esetleges felmondását követően kiállított, a tartozás minden lényeges adatát tartalmazó közjegyzői ténytanúsítvány birtokában a végrehajtási záradék kiállításának feltételei rendszerint fennálltak, így a követelés jogszerűségének előzetes vizsgálata nélkül a végrehajtás elrendelésének kérelmezése csak a pénzügyi szolgáltatón múlt. Ennek a konstrukciónak a vizsgálatát a Sugár-ügyben az Európai Unió Bírósága, valamint több ügyben az Alkotmánybíróság is vizsgálta.

Számos per indult e szerződéses kikötések tisztességtelenségének megállapítása végett. Az adósok rendszerint arra hivatkoztak, hogy e szerződéses kikötések a 18/1999. (II. 5.) Korm. rendelet 1 . $§(1)$ bekezdés b) és j) pontjait sértik, vagyis egyrészt ez a szerződéses rendelkezés a fogyasztóval szerződő felet jogosítja fel arra, hogy maga állapítsa meg a saját teljesítése megfelelőségét, másrészt a bizonyítási terhet a fogyasztó hátrányára megfordítja, hiszen előzetes tartozáselismerésnek minősül.

A Kúria elvi bírósági határozatban juttatta nyugvópontra ezt a jogkérdést, és kimondta: „Az a szerződéses rendelkezés, amely szerint a pénzügyi intézmény a saját nyilvántartásai alapulvételével jogosult a fogyasztói tartozások kimutatására, és a szerződő felek az e kimutatás alapján készült, közokiratba foglalt ténytanúsítványt tekintik irányadónak, nem minősül joghatályos tartozáselismerő nyilatkozatnak, ezért a bizonyítási terhet a fogyasztó számára hátrányosan nem változtatja meg és nem korlátozza a fogyasztó jogszabályon alapuló igényérvényesítési lehetőségét sem. Minderre tekintettel az ilyen szerződéses rendelkezés nem tisztességtelen.” A Kúria rámutatott, hogy

Pfv.V.20.868/2017/6.

Európai Tükör 2019/3. 
a fentihez hasonló tartalmú szerződéses rendelkezés a bizonyítási terhet a fogyasztó hátrányára nem fordítja meg, hiszen ez nem minősül joghatályos tartozáselismerő nyilatkozatnak, ezért nem korlátozza a fogyasztó jogszabályon alapuló igényérvényesítési lehetőségét sem. A keresettel támadott szerződéses rendelkezés nem tartalmaz a pénzintézetet a megjelölt körben megillető egyoldalú jogosítványt, nem érinti (nem vonja el) a vele szerződő fél kötelmi jogát arra, hogy a szolgáltatásának megfelelőségét megítélje és minősítse. ${ }^{40}$

\section{Felhasznált irodalom}

BALOGH László (2019): A devizahitelek tizenöt éve Magyarországon (Megjelenésük, kezelésük, nemzetközi hátterük). In BoDzÁsı Balázs szerk.: Devizahitelezés Magyarországon. A devizahitelezés jogi és közgazdasági elemzése. Budapest, Budapesti Corvinus Egyetem. 9-28.

BoDzÁsı Balázs (2018): A deviza alapú fogyasztói kölcsönszerződésekhez kapcsolódó egyes polgári jogi kérdésekről. Miskolci Jogi Szemle, 13. évf. 2. sz. 61-75.

BoDzÁsı Balázs (2019): A deviza alapú fogyasztói kölcsönökhöz kapcsolódó problémák kezelésére irányuló jogi lépések Magyarországon. In BoDzÁsı Balázs szerk.: Devizahitelezés Magyarországon. A devizahitelezés jogi és közgazdasági elemzése. Budapest, Budapesti Corvinus Egyetem. 57-93.

DANCSIK Bálint - FÁBIÁN Gergely - Fellner Zita (2019): A devizahitelezés kialakulásának körülményei - okok és okozatok. In BoDzÁsı Balázs szerk.: Devizahitelezés Magyarországon. A devizahitelezés jogi és közgazdasági elemzése. Budapest, Budapesti Corvinus Egyetem. 111-136.

FAzEKAS Judit (2016): Gondolatok a devizaalapú hitelszerződések jogi hátteréről és a tisztességtelen általános szerződési feltételek érvénytelenségi kontrolljáról. Jog - Állam - Politika, 8. évf. 4. sz. 73-96.

FAZEKAS, Judit (2017): The consumer credit crisis and unfair contract terms regulation - Before and after Kásler. Journal of European Consumer and Market Law, Vol. 6, No. 3. 99-106.

GÁRDOs István - NAGY András (2013): A devizahitel jogi alapkérdései. Hitelintézeti Szemle, 12. évf. 5. sz. 371-387.

Gomвos Katalin - LEнóczKi Balázs (2019): A tisztességtelen szerződési feltételek eltávolítása a magyarországi devizahitelszerződésekből. Jogtudományi Közlöny, 74. évf., megjelenés alatt.

JuHÁsz Krisztina (2018): A tisztességtelen szerződési feltételek hivatalbóli vizsgálata. Eljárásjogi Szemle, 3. évf. 2. sz. 40-53.

Lentner Csaba (2015): A lakossági devizahitelezés kialakulásának és konszolidációjának rendszertani vázlata. Pénzügyi Szemle, 60. évf. 3. sz. 305-318.

Simon Károly László (2019): Az árfolyamkockázatról szóló tájékoztatás hibái és jogkövetkezményei. Jogtudományi Közlöny, 74. évf., megjelenés alatt.

40 EBH2018. G.1.; BH2018. 146. 


\section{Jogforrások}

1/2016. Polgári jogegységi határozat

18/1999. (II. 5.) Korm. rendelet a fogyasztóval kötött szerződésben tisztességtelennek minősülő feltételekről

1959. évi IV. törvény a Polgári Törvénykönyvről szóló (rPtk.)

1991. évi XLI. törvény a közjegyzőkről

1996. évi CXII. törvény a hitelintézetekről és pénzügyi vállalkozásokról (rHpt.)

2/2012. (XII. 10.) PK vélemény a fogyasztói kölcsönszerződésben pénzügyi intézmény által alkalmazott általános szerződési feltételekben szereplő egyoldalú szerződésmódosítási jog tisztességtelenségéről

2/2014. Polgári jogegységi határozat

2014. évi XL. törvény a Kúriának a pénzügyi intézmények fogyasztói kölcsönszerződéseire vonatkozó jogegységi határozatával kapcsolatos egyes kérdések rendezéséről szóló 2014. évi XXXVIII. törvényben rögzített elszámolás szabályairól és egyes egyéb rendelkezésekről (DH2 törvény)

2014. évi XXXVIII. törvény a Kúriának a pénzügyi intézmények fogyasztói kölcsönszerződéseire vonatkozó jogegységi határozatával kapcsolatos egyes kérdések rendezéséről (DH1 törvény)

6/2013. Polgári jogegységi határozat

A Tanács 93/13/EGK irányelve (1993. április 5.) a fogyasztókkal kötött szerződésekben alkalmazott tisztességtelen feltételekről 